\title{
COPING STRATEGIES ADOPTED BY UNIVERSITY STUDENTS - PART II: ROLE CONFLICT AND AGE
}

\section{Ludmila Natovová, Hana Chýlová}

\begin{abstract}
This study examines the particularities of various stress coping strategies (measured by standardized stress coping strategies questionnaire SVF 78) used by undergraduate university students $(\mathrm{N}=177)$. The first part was focused on gender differences. Part II compares groups differing in age and level of family-school-work conflict, drawing on the division according to the type of study: Part-time $(\mathrm{N}=102)$ and Full-time $(\mathrm{N}=75)$ students as well as on the age distinction (age $<23: \mathrm{N}=95$, age $>24: \mathrm{N}=82$ ). The findings indicate that there are age differences, as well as differences between the groups of part-time and full-time students, in the use of stress coping strategies, especially regarding the use of the positive triad: situation control, reaction control and positive self-instruction.
\end{abstract}

\section{Key Words}

Age, coping strategy, role conflict, stress, university education
Czech University of Life Sciences Prague brozovai@pef.czu.cz

\section{ARTICLE INFO}

Article type

Full research paper

doi: 10.7160/eriesj.2012.050405

Article history

Received: October 31, 2012

Received in revised form: December 12, 2012

Accepted: December 19, 2012

Available on-line: December 30, 2012

Natovová, L., Chýlová, H. (2012) “Coping Strategies Adopted by University Students - Part II: Role Conflict and Age", Journal on Efficiency and Responsibility in Education and Science, Vol. 5, No. 4, pp. 226-238, ISSN 1803-1617, [on-line] www.eriesjournal.com/_papers/article_195.pdf 


\section{Introduction}

The issue of stress, as a common phenomenon of a contemporary, globally developing society, is studied from the research as well as practical side by many scientific disciplines such as psychosomatic or behavioural medicine, biology, psychology, sociology and pedagogy. Research into stress, coping strategies, well-being, healthy lifestyles and risk-preventing behaviour has its own irreplaceable role within pedagogical and psychological counselling work with university students.

The authors of this paper examined the particularities of various stress coping strategies (measured by standardized stress coping strategies questionnaire SVF 78) used by undergraduate university students. The first part of the results was described in: "Stress coping strategies among university students - part I: Gender differences" (Chýlová and Natovová, 2012). That paper explicitly dealt with a comparative analysis of the role of gender as a variable in relation to stress coping strategies, and the balance between the use of positive and negative strategies. The present paper (part II) focuses on other variables which play an important role in preferred stress coping strategies. The theories of stress and stress coping strategies were already described to a considerable extent in the previous paper. This part is focused directly on the specifics of the two primary remaining variables: role conflict and age. Nevertheless, the concept of coping will be defined briefly. Carver (2011, p. 222) defines coping as "efforts to deal with a threatening or harmful situation, either to remove the threat or to diminish the ways in which it can have an adverse impact on the person."

A relationship between coping and psychological well-being has been found in a number of studies. One of the most influential is Folkman et al. (1987), who also focused on age differences in stress and coping processes, and clearly demonstrated the role of age in coping. They formulated three predictions; the third one involves an interaction between gender and age. However, they also mention a so-called "contextual interpretation", which suggests that there should be no age differences in the ways people cope with similar sources of stress.

A study conducted in Italy (Cicognani, 2011), which examined coping strategies for minor stressors in adolescence, suggests that the majority of adolescents are successful in coping and productive adaptation - the most frequently used strategies in that study were active and internally focused.

The effect of age, as a variable affecting the relationship between stressors and performance, has received attention in the occupational stress literature for quite some time, even though the attention that has been given to this demographic variable has been, according to Jex (1998), more conceptual than empirical.

One of the major approaches to the stress process is the role stress model. Griffin and Clarke (2011, p. 362) assume that "the process through which work roles create the experience of stress was one of the earliest and most fruitful approaches to work stress." These authors (Griffin and Clarke, 2011) also define role conflict as two or more sets of incompatible work demands, and role overload is considered a particular form of role conflict.

The moderator role of coping (problem-, emotion-, and avoidance-focused coping strategies) between work-to-family and family-to-work conflict and well-being (work engagement, job satisfaction, and family satisfaction) was examined by Rantanen (2011). Analyses showed that emotion-focused coping buffered against job dissatisfaction in a strong familyto-work conflict situation. On the other hand, emotion-focused coping was harmful for family satisfaction in the same stressful situation: Those who used more emotion-focused coping were 
less satisfied with their family life under the conditions of strong family-to-work conflict. Furthermore, avoidance coping was beneficial in a strong family-to-work conflict situation: Those who used more avoidance coping were more satisfied with their family life in this situation.

Baltes, Zhdanova and Clark (2011) examined the processes through which personality characteristics can influence work-family conflict. Specifically, they tested the mediating effects of selection, optimization, and compensation behavioural stress-coping strategies on the relationship between personality characteristics and work-family conflict. Conscientiousness and agreeableness were related to greater usage of work and family behavioural coping strategies, and these behavioural strategies influenced the levels of workfamily conflict that were experienced. Work interference with family, as well as family interference with work, were found to have negative direct effects, and emotional stability was found to have a direct effect on that conflict. The findings suggest that different processes underlie the influence of specific personality characteristics on the work-family conflict.

The role conflict of a student-worker-mother/father is particularly expressed in the group of part-time students, and also in the older group of students. Coping mechanisms of students were studied by, among others, Caplan, Naidu and Tripathi (1984), who studied coping mechanisms used by a group of university students facing the stress of annual examination. Their results suggest that coping may mitigate the effects of stressors on well-being only when the stressors are subjectively controllable. A study by McLaughlin, Cormier and Cormier (1988) closely examined the relationship between timemanagement and self-care coping techniques used by multiplerole women, and their self-reported levels of distress, stress and marital adjustment. The results of the study indicated that the number, type and frequency of use of coping strategies were significantly related to the self-reported level of distress and stress.

Role conflict and age specifics, being variables in the use of different stress coping techniques and having an influence on students' well-being, is the subject matter of this text.

\section{Materials and Methods}

\section{Group of respondents}

The Czech version of the Stress Coping Style Questionnaire SVF 78 was administered to 177 undergraduate students from September 2011 to January 2012. The sample consisted of 63 males and 114 females in the age range from 19 to 49 years. Of the total number of 177 students, 102 were part-time students and 75 were full-time students at the Faculty of Economics and Management (FEM) at the Czech University of Life Sciences (CULS) within the study programmes Public Administration, Regional Development, and Business and Administration. 95 students were 23 years old or younger, and the group of older students consisted of 82 students. Even though students typically finish their university studies around the age of 23 , this is often not the case, and therefore merely age and/or type of study cannot be considered all-inclusive categories. We expect that role conflict, mainly for part-time students, and the age variable of any student will be important moderators of stress coping strategies.

The subjects were not paid. Further descriptive characteristics are presented in Tab. 1, below. 


\begin{tabular}{|c|c|c|c|c|c|c|c|c|}
\hline & N & $\begin{array}{c}\text { Mean } \\
\text { Age }\end{array}$ & $\begin{array}{c}\text { Stand. } \\
\text { dev. }\end{array}$ & $\begin{array}{c}\text { Min. } \\
\text { Age }\end{array}$ & $\begin{array}{c}\text { Max. } \\
\text { Age }\end{array}$ & $\begin{array}{c}\text { Women } \\
(\mathrm{N})\end{array}$ & $\begin{array}{c}\text { Women } \\
(\%)\end{array}$ & $\begin{array}{c}\text { School- } \\
\text { work- } \\
\text { family } \\
\text { conflict } \\
(\%)\end{array}$ \\
\hline $\begin{array}{c}\text { Part-time } \\
\text { students }\end{array}$ & 102 & 30,17 & 7,44 & 20 & 49 & 52 & 50,98 & $100^{*}$ \\
\hline $\begin{array}{c}\text { Full-time } \\
\text { students }\end{array}$ & 75 & 20,89 & 0,92 & 19 & 26 & 62 & 82,67 & $0 *$ \\
\hline $\begin{array}{c}\text { Younger } \\
\text { students } \\
(19-23)\end{array}$ & 95 & 20,92 & 0,83 & 19 & 23 & 64 & 67,4 & 22,1 \\
\hline $\begin{array}{c}\text { Older } \\
\text { students } \\
(24-49)\end{array}$ & 82 & 32,4 & 6,57 & 24 & 49 & 50 & 61,0 & 98,8 \\
\hline \multicolumn{1}{c|}{ Total } & 177 & 26,24 & 7,29 & 19 & 49 & 114 & 64,41 & 57,6 \\
\hline
\end{tabular}

*expected value (no input data)

Tab. 1: Descriptive characteristics of subgroups of respondents.

\section{The method}

In the Czech version of the SVF 78 questionnaire, subjects decide for each item how likely the reaction presented corresponds to his or her way of reacting, when he/she is "disturbed, irritated or upset by something or someone" (Weyers et al, 2005; Janke and Erdmann, 2003). The inventory contains 78 items and has 13 subscales. Scales $1-7$ are assumed as positive coping strategies, scales $10-13$ as negative coping strategies. Scales (and their abbreviations, which are used also further in the text) with short descriptions and sample-items are summarized in Tab. 2.

\begin{tabular}{|c|c|c|c|}
\hline Abbrev. & Name & Description & Sample-item \\
\hline MIN & Minimization & $\begin{array}{c}\text { devaluate intensity, } \\
\text { duration or importance of } \\
\text { stress } \\
\end{array}$ & $\begin{array}{l}\text { I tell myself that } \\
\text { everything will } \\
\text { turn out all right }\end{array}$ \\
\hline DENGU & Denial of Guilt & $\begin{array}{l}\text { stress one's missing } \\
\text { personal responsibility }\end{array}$ & $\begin{array}{c}\text { I think that I am } \\
\text { not responsible for } \\
\text { the situation }\end{array}$ \\
\hline DISTR & Distraction & $\begin{array}{l}\text { distract from stress related } \\
\text { activities/situations or } \\
\text { turn to stress incompatible } \\
\text { ones }\end{array}$ & $\begin{array}{l}\text { I try to distract } \\
\text { myself }\end{array}$ \\
\hline SUB & $\begin{array}{l}\text { Substitute } \\
\text { Gratification }\end{array}$ & $\begin{array}{l}\text { turn to positive activities/ } \\
\text { situations }\end{array}$ & $\begin{array}{c}\text { I grant myself } \\
\text { something I've } \\
\text { desired for a long } \\
\text { time }\end{array}$ \\
\hline SITCON & $\begin{array}{l}\text { Situation } \\
\text { Control }\end{array}$ & $\begin{array}{l}\text { analyze the situation, plan } \\
\text { actions and act for control } \\
\text { and problem solving }\end{array}$ & $\begin{array}{c}\text { I plan how to solve } \\
\text { the difficulties } \\
\text { involved }\end{array}$ \\
\hline RECON & $\begin{array}{c}\text { Response } \\
\text { Control }\end{array}$ & $\begin{array}{l}\text { bring or keep one's own } \\
\text { reactions under control }\end{array}$ & $\begin{array}{l}\text { I tell myself I must } \\
\text { not lose my temper }\end{array}$ \\
\hline POSI & $\begin{array}{l}\text { Positive Self- } \\
\text { instructions }\end{array}$ & $\begin{array}{l}\text { encourage oneself } \\
\text { competence and the } \\
\text { ability to control }\end{array}$ & $\begin{array}{l}\text { I tell myself that I } \\
\text { can cope with this }\end{array}$ \\
\hline SOCSUP & $\begin{array}{l}\text { Need for } \\
\text { Social Support }\end{array}$ & $\begin{array}{c}\text { look out for somebody to } \\
\text { talk to, for social support } \\
\text { and help }\end{array}$ & $\begin{array}{l}\text { I try to talk with } \\
\text { someone about the } \\
\text { problem }\end{array}$ \\
\hline AVOID & Avoidance & $\begin{array}{l}\text { resolve to prevent or avoid } \\
\text { stressful situations }\end{array}$ & $\begin{array}{l}\text { I resolve to avoid } \\
\text { such situations in } \\
\text { the future }\end{array}$ \\
\hline ESC & Escape & $\begin{array}{l}\text { (resignative) tendency to } \\
\text { escape a stressful situation }\end{array}$ & $\begin{array}{l}\text { I tend to run away } \\
\text { from the situation }\end{array}$ \\
\hline RUMI & Rumination & $\begin{array}{l}\text { ruminate, not being able } \\
\text { to break off from one's } \\
\text { thoughts }\end{array}$ & $\begin{array}{l}\text { I keep thinking } \\
\text { about the situation } \\
\text { for a long time } \\
\text { afterwards }\end{array}$ \\
\hline RES & Resignation & $\begin{array}{c}\text { give up with feelings of } \\
\text { helplessness, hopelessness }\end{array}$ & I tend to give up \\
\hline SEBLA & Self-blame & $\begin{array}{l}\text { attribute stress to one's } \\
\text { own mistakes }\end{array}$ & I blame myself \\
\hline
\end{tabular}

Tab. 2: SVF78 Subtests and Categories (Weyers et al, 2005). 


\section{Statistical Analyses}

As was mentioned above, this study attempts to identify differences in the use of coping strategies by students in different study modes, specifically in the full-time and parttime studies. With respect to findings cited in Introduction, we have formulated first hypothesis that there are statistically significant differences in the use of coping strategies between the group of full-time students and the group of part-time students, identified through the SVF 78 questionnaire. The second hypothesis assumes significant differences in the use of coping strategies between younger (age 18 -23) and older (age $24-50$ ) participants. To identify differences between each group of participants (full-time students, part-time students, students in age group $18-23$ years, student in age group $24-50$ years) and standardized sample from Czech population we use one sample $t$ test. To test the null hypothesis of non-existence of a significant difference between the two groups, we used a $t$ test for two independent samples (Norušis, 2011). Before each testing, the null hypothesis of no difference in the variance of the evaluated variable values in both groups was adopted based on Levene's Test for Equality of Variances.

\section{Results}

With regard to the above-mentioned hypotheses, the results presented below are logically divided into two parts. First, we refer to the differences between students of the two types of study and a standardized Czech population sample (Tab. 3), and also between both groups of students according to their study mode (Tab. 4). The second part of the results includes an age differentiated comparison of our sample to the Czech population sample (Tab. 5), as well as a mutual comparison of both age groups (Tab. 6). The first question posed was whether one of our groups (full-time or part-time students) is more similar to the standardized Czech population sample than the other group. Tab. 3, below, shows the results of one sample t-test for each of these groups, for all observed coping strategies.

\begin{tabular}{|c|c|c|c|c|c|c|c|c|}
\hline \multirow[t]{2}{*}{ Strategy } & \multirow{2}{*}{ study mode } & \multirow[t]{2}{*}{$t$} & \multirow[t]{2}{*}{$\mathrm{df}$} & \multirow[t]{2}{*}{$\begin{array}{c}\text { Sig. } \\
\text { (2-tailed) }\end{array}$} & \multirow[t]{2}{*}{$\begin{array}{l}\text { Mean } \\
\text { Diff. }\end{array}$} & \multicolumn{2}{|c|}{$\begin{array}{c}95 \% \\
\text { Confidence } \\
\text { Interval of the } \\
\text { Difference }\end{array}$} & \multirow{2}{*}{$\begin{array}{l}\text { Test } \\
\text { Value }\end{array}$} \\
\hline & & & & & & Lower & Upper & \\
\hline \multirow{2}{*}{ MIN } & Part-time & 4,73 & 101 & $0,00^{* *}$ & 2,37 & 1,38 & 3,37 & \multirow{2}{*}{9.48} \\
\hline & Full-time & 0,00 & 74 & 1,00 & 0,00 & $-1,21$ & 1,21 & \\
\hline \multirow{2}{*}{ DENGU } & Part-time & 2,27 & 101 & $0,03^{*}$ & 0,84 & 0,11 & 1,57 & \multirow{2}{*}{10.71} \\
\hline & Full-time & 0,76 & 74 & 0,45 & 0,38 & $-0,63$ & 1,39 & \\
\hline \multirow{2}{*}{ DISTR } & Part-time & 1,35 & 101 & 0,18 & 0,56 & $-0,27$ & 1,39 & \multirow{2}{*}{11.83} \\
\hline & Full-time & 3,30 & 74 & $0,00^{* *}$ & 1,44 & 0,57 & 2,30 & \\
\hline \multirow{2}{*}{ SUB } & Part-time & 5,84 & 101 & $0,00^{* *}$ & 2,51 & 1,66 & 3,37 & \multirow{2}{*}{8.91} \\
\hline & Full-time & 6,81 & 74 & $0,00^{* *}$ & 3,32 & 2,35 & 4,29 & \\
\hline \multirow{2}{*}{ SITCON } & Part-time & $-0,36$ & 101 & 0,72 & $-0,13$ & $-0,88$ & 0,61 & \multirow{2}{*}{16.78} \\
\hline & Full-time & $-4,12$ & 74 & $0,00^{* *}$ & $-2,05$ & $-3,04$ & $-1,06$ & \\
\hline \multirow{2}{*}{ RECON } & Part-time & 1,51 & 101 & 0,13 & 0,57 & $-0,18$ & 1,32 & \multirow{2}{*}{15.41} \\
\hline & Full-time & $-1,40$ & 74 & 0,17 & $-0,61$ & $-1,48$ & 0,26 & \\
\hline \multirow{2}{*}{ POSI } & Part-time & $-0,481$ & 101 & 0,63 & $-0,22$ & $-1,14$ & 0,70 & \multirow{2}{*}{16.37} \\
\hline & Full-time & $-3,74$ & 74 & $0,00^{* *}$ & $-2,01$ & $-3,08$ & $-0,94$ & \\
\hline
\end{tabular}




\begin{tabular}{|c|c|c|c|c|c|c|c|c|}
\hline \multirow{2}{*}{ SOCSUP } & Part-time & 4,35 & 101 & $0,00^{* *}$ & 2,19 & 1,19 & 3,19 & \multirow{2}{*}{12,89} \\
\hline & Full-time & 5,28 & 74 & $0,00^{* *}$ & 2,98 & 1,85 & 4,10 & \\
\hline \multirow{2}{*}{ AVOID } & Part-time & 8,45 & 101 & $0,00^{* *}$ & 3,35 & 2,57 & 4,14 & \multirow{2}{*}{11.97} \\
\hline & Full-time & 5,05 & 74 & $0,00^{* *}$ & 2,76 & 1,67 & 3,86 & \\
\hline \multirow{2}{*}{ ESC } & Part-time & 6,33 & 101 & $0,00^{* *}$ & 2,84 & 1,95 & 3,73 & \multirow{2}{*}{8.24} \\
\hline & Full-time & 7,51 & 74 & $0,00^{* *}$ & 3,77 & 2,77 & 4,77 & \\
\hline \multirow{2}{*}{ RUMI } & Part-time & 0,30 & 101 & 0,77 & 0,15 & $-0,87$ & 1,18 & \multirow{2}{*}{15.13} \\
\hline & Full-time & 0,42 & 74 & 0,68 & 0,27 & $-1,01$ & 1,55 & \\
\hline \multirow{2}{*}{ RES } & Part-time & 1,90 & 101 & 0,06 & 1,00 & $-0,04$ & 2,04 & \multirow{2}{*}{8.04} \\
\hline & Full-time & 4,82 & 74 & $0,00^{* *}$ & 2,60 & 1,53 & 3,67 & \\
\hline \multirow{2}{*}{ SEBLA } & Part-time & 1,84 & 101 & 0,07 &, 87 & $-0,07$ & 1,81 & \multirow{2}{*}{10.64} \\
\hline & Full-time & 1,82 & 74 & 0,07 & 1,15 & $-0,11$ & 2,40 & \\
\hline \multirow{2}{*}{$\begin{array}{l}\text { Positive } \\
\text { strategies } \\
\text { total }\end{array}$} & Part-time & 5,82 & 101 & $0,00^{* *}$ & 1,49 & 0,98 & 2,00 & \multirow[t]{2}{*}{12.22} \\
\hline & Full-time & 1,90 & 74 & 0,06 & 0,63 & $-0,03$ & 1,29 & \\
\hline \multirow{2}{*}{$\begin{array}{c}\text { Negative } \\
\text { strategies } \\
\text { total }\end{array}$} & Part-time & 2,87 & 101 & $0,01^{* *}$ & 1,21 & 0,37 & 2,04 & \multirow{2}{*}{10.52} \\
\hline & Full-time & 4,18 & 74 & $0,00^{* *}$ & 1,94 & 1,02 & 2,86 & \\
\hline
\end{tabular}

denial of guilt and substitution, significantly more often. Fulltime students use the strategies of distraction, substitution and resignation more often than participants from the standardized sample, but use the strategies of controlling the situation and giving oneself positive instructions significantly less. This fact is important for counselling work and also for training and educative activities in some of the subjects taught in the department of psychology (e.g., Mental hygiene), and it will also be scrutinized with regard to age-differentiated groups. Both of our groups (full-time and part-time students) use the neutral strategies of seeking social support and avoiding stressors, as well as the strategy of escaping stressful situations, more frequently.

With regard to the above-mentioned hypotheses, in each of the two independent samples (full-time students and parttime students), we separately tested the average values of each variable - i.e., coping strategies identified through the SVF 78 questionnaire (described in detail in Tab. 2 above). Tab. 4, below, summarizes the descriptive characteristics of each variable, Levene's test results and the t-test results for two independent samples.

Tab. 3: Results - descriptive statistics and one sample t-test of study modes

As shown in Tab. 3, some significant differences were identified between the observed groups of students, according to their study mode, and the entire Czech population (mean values of each strategy are presented in Tab. 4, below). Part-time students use some of the positive strategies, such as minimization, 
Journal on Efficiency and Responsibility in Education and Science

ISSN: 1803-1617, doi: 10.7160/eriesj.2012.050405

\begin{tabular}{|c|c|c|c|c|c|c|c|c|c|c|}
\hline \multirow[t]{2}{*}{ Strategy } & \multirow{2}{*}{$\begin{array}{l}\text { Type } \\
\text { of } \\
\text { study }\end{array}$} & \multirow[t]{2}{*}{ Mean } & \multirow[t]{2}{*}{$\begin{array}{l}\text { Std. } \\
\text { Dev. }\end{array}$} & \multicolumn{2}{|c|}{$\begin{array}{l}\text { Levene's } \\
\text { tests }\end{array}$} & \multirow{2}{*}{\multicolumn{2}{|c|}{$\begin{array}{l}\mathrm{t} \text { tests } \\
\text { Sig. }\end{array}$}} & \multirow[t]{2}{*}{$\begin{array}{l}\text { Mean } \\
\text { Diff. }\end{array}$} & \multicolumn{2}{|c|}{$\begin{array}{l}95 \% \text { Confidence } \\
\text { Interval of the } \\
\text { Difference }\end{array}$} \\
\hline & & & & $\mathrm{F}$ & & & & & Lower & Upper \\
\hline \multirow{2}{*}{ MIN } & $\begin{array}{l}\text { Part- } \\
\text { time }\end{array}$ & 11,85 & 5,07 & \multirow{2}{*}{0,17} & \multirow{2}{*}{0,68} & \multirow{2}{*}{3,03} & \multirow{2}{*}{$0,00^{* *}$} & \multirow{2}{*}{2,37} & \multirow{2}{*}{0,83} & \multirow{2}{*}{3,92} \\
\hline & $\begin{array}{l}\text { Full- } \\
\text { time }\end{array}$ & 9,48 & 5,24 & & & & & & & \\
\hline \multirow{2}{*}{ DENGU } & $\begin{array}{l}\text { Part- } \\
\text { time }\end{array}$ & 11,55 & 3,73 & \multirow{2}{*}{0,85} & \multirow{2}{*}{0,36} & \multirow{2}{*}{0,74} & \multirow{2}{*}{0,46} & \multirow{2}{*}{0,46} & \multirow{2}{*}{$-0,75$} & \multirow{2}{*}{1,66} \\
\hline & $\begin{array}{l}\text { Full- } \\
\text { time }\end{array}$ & 11,09 & 4,40 & & & & & & & \\
\hline \multirow{2}{*}{ DISTR } & $\begin{array}{l}\text { Part- } \\
\text { time }\end{array}$ & 12,39 & 4,22 & \multirow{2}{*}{1,51} & \multirow{2}{*}{0,22} & \multirow{2}{*}{$-1,43$} & \multirow{2}{*}{0,16} & \multirow{2}{*}{$-0,87$} & \multirow{2}{*}{$-2,09$} & \multirow{2}{*}{0,34} \\
\hline & $\begin{array}{l}\text { Full- } \\
\text { time }\end{array}$ & 13,27 & 3,77 & & & & & & & \\
\hline \multirow{2}{*}{ SUB } & $\begin{array}{l}\text { Part- } \\
\text { time }\end{array}$ & 11,42 & 4,35 & \multirow{2}{*}{0,49} & \multirow{2}{*}{0,49} & \multirow{2}{*}{$-1,23$} & \multirow{2}{*}{0,22} & & & \\
\hline & $\begin{array}{l}\text { Full- } \\
\text { time }\end{array}$ & 12,23 & 4,22 & & & & & $-0,01$ & - 2,0 & o, \\
\hline & $\begin{array}{l}\text { Part- } \\
\text { time }\end{array}$ & 16,65 & 3,79 & & & & & & & \\
\hline S18 & $\begin{array}{l}\text { Full- } \\
\text { time }\end{array}$ & 14,73 & 4,30 & 1,13 & 0,10 & 0,14 & 0,02 & & $0, / 1$ & 3,12 \\
\hline & $\begin{array}{l}\text { Part- } \\
\text { time }\end{array}$ & 15,98 & 3,81 & & & & & & & \\
\hline & $\begin{array}{l}\text { Full- } \\
\text { time }\end{array}$ & 14,80 & 3,77 & & & & & & & \\
\hline
\end{tabular}

\begin{tabular}{|c|c|c|c|c|c|c|c|c|c|c|}
\hline \multirow{2}{*}{ POSI } & $\begin{array}{l}\text { Part- } \\
\text { time }\end{array}$ & 16,15 & 4,68 & \multirow{2}{*}{0,09} & \multirow{2}{*}{0,77} & \multirow{2}{*}{2,52} & \multirow{2}{*}{$0,01^{* *}$} & \multirow{2}{*}{1,79} & \multirow{2}{*}{0,39} & \multirow{2}{*}{3,19} \\
\hline & $\begin{array}{l}\text { Full- } \\
\text { time }\end{array}$ & 14,36 & 4,66 & & & & & & & \\
\hline \multirow{2}{*}{ SOCSUP } & $\begin{array}{l}\text { Part- } \\
\text { time }\end{array}$ & 15,08 & 5,09 & \multirow{2}{*}{1,19} & \multirow{2}{*}{0,28} & \multirow{2}{*}{$-1,04$} & \multirow{2}{*}{0,30} & \multirow{2}{*}{$-0,79$} & \multirow{2}{*}{$-2,29$} & \multirow{2}{*}{0,71} \\
\hline & $\begin{array}{l}\text { Full- } \\
\text { time }\end{array}$ & 15,87 & 4,88 & & & & & & & \\
\hline \multirow{2}{*}{ AVOID } & $\begin{array}{l}\text { Part- } \\
\text { time }\end{array}$ & 15,32 & 4,01 & \multirow{2}{*}{2,00} & \multirow{2}{*}{0,16} & \multirow{2}{*}{0,90} & \multirow{2}{*}{0,37} & \multirow{2}{*}{0,59} & \multirow{2}{*}{$-0,71$} & \multirow{2}{*}{1,89} \\
\hline & $\begin{array}{l}\text { Full- } \\
\text { time }\end{array}$ & 14,73 & 4,74 & & & & & & & \\
\hline \multirow{2}{*}{ ESC } & $\begin{array}{l}\text { Part- } \\
\text { time }\end{array}$ & 11,08 & 4,53 & \multirow{2}{*}{0,00} & \multirow{2}{*}{1,00} & \multirow{2}{*}{$-1,38$} & \multirow{2}{*}{0,17} & \multirow{2}{*}{$-0,93$} & \multirow{2}{*}{$-2,27$} & \multirow{2}{*}{0,40} \\
\hline & $\begin{array}{l}\text { Full- } \\
\text { time }\end{array}$ & 12,01 & 4,35 & & & & & & & \\
\hline \multirow{2}{*}{ RUMI } & $\begin{array}{l}\text { Part- } \\
\text { time }\end{array}$ & 15,28 & 5,20 & \multirow{2}{*}{1,24} & \multirow{2}{*}{0,27} & \multirow{2}{*}{$-0,14$} & \multirow{2}{*}{0,89} & & & \\
\hline & $\begin{array}{l}\text { Full- } \\
\text { time }\end{array}$ & 15,40 & 5,58 & & & & & & & \\
\hline & $\begin{array}{l}\text { Part- } \\
\text { time }\end{array}$ & 9,04 & 5,31 & & & & & & & \\
\hline & $\begin{array}{l}\text { Full- } \\
\text { time }\end{array}$ & 10,64 & 4,67 & & & & & & & \\
\hline & $\begin{array}{l}\text { Part- } \\
\text { time }\end{array}$ & 11,51 & 4,77 & & & & & & & \\
\hline & $\begin{array}{l}\text { Full- } \\
\text { time }\end{array}$ & 11,79 & 5,45 & & & & & & & \\
\hline
\end{tabular}




\begin{tabular}{|c|c|c|c|c|c|c|c|c|c|c|}
\hline \multirow{2}{*}{$\begin{array}{c}\text { Positive } \\
\text { strategies } \\
\text { total }\end{array}$} & $\begin{array}{l}\text { Part- } \\
\text { time }\end{array}$ & 13,71 & 2,59 & \multirow{2}{*}{0,31} & \multirow{2}{*}{0,58} & \multirow{2}{*}{2,09} & \multirow{2}{*}{$0,038^{*}$} & \multirow{2}{*}{0,86} & \multirow{2}{*}{0,05} & \multirow{2}{*}{1,68} \\
\hline & $\begin{array}{l}\text { Full- } \\
\text { time }\end{array}$ & 12,85 & 2,87 & & & & & & & \\
\hline \multirow{2}{*}{$\begin{array}{c}\text { Negative } \\
\text { strategies } \\
\text { total }\end{array}$} & $\begin{array}{l}\text { Part- } \\
\text { time }\end{array}$ & 11,72 & 4,25 & \multirow{2}{*}{0,25} & \multirow{2}{*}{0,62} & \multirow{2}{*}{$-1,16$} & \multirow{2}{*}{0,25} & \multirow{2}{*}{$-0,73$} & \multirow{2}{*}{$-1,98$} & \multirow{2}{*}{0,51} \\
\hline & $\begin{array}{l}\text { Full- } \\
\text { time }\end{array}$ & 12,46 & 4,02 & & & & & & & \\
\hline
\end{tabular}

Tab. 4: Results - descriptive statistics and two independent samples t-tests for each coping strategy, with Levene's Tests for Equality of Variances

Data in Tab. 4 indicate a significant difference in the use of the minimization, situation control, response control and positive self-instruction strategies. Among the negative strategies, only the difference in the use of the resignation strategy has proved significant. In relation to the descriptive characteristics of the evaluated variable, we can also state that a strategy was used more frequently in the group of full-time or part-time students. As for the minimization strategy, it consists in an intentional or conscious reduction in the intensity, duration or importance of a stressor in a particular situation. This strategy is classified as a positive coping strategy, and its more frequent use among parttime students (also according to the entire Czech population, as presented above) may be related to their different life experience, given the higher age of students in this group; compare Tab. 1. The three strategies of situation control, response control and positive self-instruction are described by theSVF 78 questionnaire authors (Janke and Erdmann, 2003) as a separate triplet, ranking among the positive coping strategies which prove to be the most constructive in coping with stress. In practice, we can say that the use of these three positive coping strategies can be a good predictor of dealing with stressful situations, and is associated, though probably not entirely, with handling the demands of part-time university study. The last significant difference identified in our sample was that part-time students used the resignation strategy less than full-time students; nevertheless, both of the observed groups scored significantly higher in this strategy than the Czech population sample. This strategy is one of the non-constructive, negative strategies of coping with stress. However, with respect to the use of this strategy by fulltime students, psychological interventions during face-to-face instruction need to be considered, such as the presentation of topics related to the causal attribution theory, locus of control or logotherapeutic approach.

With regard to the hypotheses of significant differences in the use of coping strategies, in both age groups and in each of the two independent samples (younger students of age 18 - 23 years and older students of age $24-50$ years), we separately tested the average values of each variable - i.e., coping strategies identified through the SVF 78 questionnaire (described in detail in Tab. 2 above). The second question posed was whether one of our groups (younger or older students) is more similar to the standardized Czech population sample than the other group. Tab. 5 shows the results of one sample t-test for each of these groups, for all coping strategies. Tab. 6 summarizes the descriptive characteristics of each variable, Levene's test results and the t-test results for two independent samples. 


\begin{tabular}{|c|c|c|c|c|c|c|c|c|}
\hline \multirow{2}{*}{ Strategy } & \multirow{2}{*}{$\begin{array}{l}\text { Age } \\
\text { group }\end{array}$} & \multirow[t]{2}{*}{$\mathrm{t}$} & \multirow[t]{2}{*}{$\mathrm{df}$} & \multirow{2}{*}{$\begin{array}{c}\text { Sig. } \\
\text { (2-tailed) }\end{array}$} & \multirow{2}{*}{$\begin{array}{c}\text { Mean } \\
\text { Diff. }\end{array}$} & \multicolumn{2}{|c|}{$\begin{array}{l}95 \% \text { Confidence } \\
\text { Interval of the } \\
\text { Difference }\end{array}$} & \multirow{2}{*}{ Test Value } \\
\hline & & & & & & Lower & Upper & \\
\hline \multirow{2}{*}{ MIN } & $18-23$ & 0,93 & 94 & 0,35 & 0,52 & $-0,59$ & 1,63 & \multirow{2}{*}{9.48} \\
\hline & $24-50$ & 4,33 & 81 & $0,00^{* *}$ & 2,35 & 1,27 & 3,43 & \\
\hline \multirow{2}{*}{ DENGU } & $18-23$ & 0,56 & 94 & 0,58 & 0,24 & $-0,61$ & 1,09 & \multirow{2}{*}{10.71} \\
\hline & $24-50$ & 2,66 & 81 & $0,01^{* *}$ & 1,12 & 0,28 & 1,96 & \\
\hline \multirow{2}{*}{ DISTR } & $18-23$ & 3,45 & 94 & $0,00^{* *}$ & 1,42 & 0,60 & 2,24 & \multirow{2}{*}{11.83} \\
\hline & $24-50$ & 0,82 & 81 & 0,41 & 0,37 & $-0,52$ & 1,25 & \\
\hline \multirow{2}{*}{ SUB } & $18-23$ & 7,48 & 94 & $0,00^{* *}$ & 3,13 & 2,30 & 3,96 & \multirow{2}{*}{8.91} \\
\hline & $24-50$ & 5,04 & 81 & $0,00^{* *}$ & 2,53 & 1,53 & 3,53 & \\
\hline \multirow{2}{*}{ SITCON } & $18-23$ & $-4,13$ & 94 & $0,00^{* *}$ & $-1,77$ & $-2,62$ & $-0,92$ & \multirow{2}{*}{16.78} \\
\hline & $24-50$ & 0,03 & 81 & 0,98 & 0,01 & $-0,83$ & 0,86 & \\
\hline \multirow{2}{*}{ RECON } & $18-23$ & $-1,25$ & 94 & 0,22 & $-0,48$ & $-1,25$ & 0,29 & \multirow{2}{*}{15.41} \\
\hline & $24-50$ & 1,69 & 81 & 0,09 & 0,71 & $-0,12$ & 1,55 & \\
\hline \multirow{2}{*}{ POSI } & $18-23$ & $-3,60$ & 94 & $0,00^{* *}$ & $-1,78$ & $-2,76$ & $-0,80$ & \multirow{2}{*}{16.37} \\
\hline & $24-50$ & $-0,11$ & 81 & 0,92 & $-0,05$ & $-1,04$ & 0,93 & \\
\hline \multirow{2}{*}{ SOCSUP } & $18-23$ & 5,73 & 94 & $0,00^{* * *}$ & 2,93 & 1,92 & 3,95 & \multirow{2}{*}{12,89} \\
\hline & $24-50$ & 3,71 & 81 & $0,00^{* *}$ & 2,05 & 0,95 & 3,15 & \\
\hline \multirow{2}{*}{ AVOID } & $18-23$ & 6,57 & 94 & $0,00^{* *}$ & 3,02 & 2,11 & 3,93 & \multirow{2}{*}{11.97} \\
\hline & $24-50$ & 6,93 & 81 & $0,00^{* *}$ & 3,20 & 2,28 & 4,12 & \\
\hline
\end{tabular}

\begin{tabular}{|c|c|c|c|c|c|c|c|c|}
\hline \multirow{2}{*}{ ESC } & $18-23$ & 8,69 & 94 & $0,00^{* *}$ & 3,82 & 2,95 & 4,70 & \multirow{2}{*}{8.24} \\
\hline & $24-50$ & 5,03 & 81 & $0,00^{* *}$ & 2,55 & 1,54 & 3,56 & \\
\hline \multirow{2}{*}{ RUMI } & $18-23$ & 0,12 & 94 & 0,90 & 0,07 & $-1,05$ & 1,19 & \multirow{2}{*}{15.13} \\
\hline & $24-50$ & 0,63 & 81 & 0,53 & 0,36 & $-0,78$ & 1,50 & \\
\hline \multirow{2}{*}{ RES } & $18-23$ & 4,64 & 94 & $0,00^{* *}$ & 2,34 & 1,34 & 3,34 & \multirow{2}{*}{8.04} \\
\hline & $24-50$ & 1,58 & 81 & 0,12 & 0,91 & $-0,24$ & 2,06 & \\
\hline \multirow{2}{*}{ SEBLA } & $18-23$ & 2,34 & 94 & $0,02^{*}$ & 1,27 & 0,19 & 2,34 & \multirow{2}{*}{10.64} \\
\hline & $24-50$ & 1,25 & 81 & 0,21 & 0,66 & $-0,39$ & 1,72 & \\
\hline \multirow{2}{*}{$\begin{array}{l}\text { Positive } \\
\text { strategies } \\
\text { total }\end{array}$} & $18-23$ & 2,53 & 94 & $0,01^{* *}$ & 0,75 & 0,16 & 1,33 & \multirow{2}{*}{12.22} \\
\hline & $24-50$ & 5,64 & 81 & $0,00^{* *}$ & 1,57 & 1,02 & 2,12 & \\
\hline \multirow{2}{*}{$\begin{array}{l}\text { Negative } \\
\text { strategies } \\
\text { total }\end{array}$} & $18-23$ & 4,43 & 94 & $0,00^{* *}$ & 1,87 & 1,03 & 2,70 & \multirow{2}{*}{10.52} \\
\hline & $24-50$ & 2,40 & 81 & $0,02^{*}$ & 1,11 & 0,19 & 2,04 & \\
\hline
\end{tabular}

Tab. 5: Results - descriptive statistics and one sample t-test of each age group coping strategies compared to the population sample

As in the case of full-time and part-time students, in this case we can also identify significant differences between older students and participants from the Czech population sample with regard to the strategy of minimization and denial of guilt (older students use these strategies more frequently). Younger students use the strategies of distraction, resignation and selfblame (resignation and self-blame are clearly negative coping strategies) more frequently than the Czech population, but the strategies of positive self-instruction and situation control less frequently. Both of our groups use the strategies of substitution, 
social support, avoidance and escaping more often than the Czech population sample.

\begin{tabular}{|c|c|c|c|c|c|c|c|c|c|c|}
\hline \multirow[t]{2}{*}{ Strategy } & \multirow[t]{2}{*}{$\begin{array}{l}\text { Age } \\
\text { group }\end{array}$} & \multirow[t]{2}{*}{ Mean } & \multirow[t]{2}{*}{$\begin{array}{l}\text { Std. } \\
\text { Dev. }\end{array}$} & \multicolumn{2}{|c|}{$\begin{array}{l}\text { Levene's } \\
\text { tests }\end{array}$} & \multirow{2}{*}{\multicolumn{2}{|c|}{$\begin{array}{l}\mathrm{t} \text { tests } \\
\text { Sig. }\end{array}$}} & \multirow[t]{2}{*}{$\begin{array}{l}\text { Mean } \\
\text { Diff. }\end{array}$} & \multicolumn{2}{|c|}{$\begin{array}{l}95 \% \text { Confidence } \\
\text { Interval of the } \\
\text { Difference }\end{array}$} \\
\hline & & & & & & & & & Lower & Upper \\
\hline \multirow{2}{*}{ MIN } & $18-23$ & 10,00 & 5,43 & \multirow{2}{*}{1,16} & \multirow{2}{*}{0,28} & \multirow{2}{*}{$-2,34$} & \multirow{2}{*}{$0,02^{*}$} & \multirow{2}{*}{$-1,83$} & \multirow{2}{*}{$-3,38$} & \multirow{2}{*}{$-0,28$} \\
\hline & $24-50$ & 11,83 & 4,91 & & & & & & & \\
\hline \multirow{2}{*}{ DENGU } & $18-23$ & 10,95 & 4,17 & \multirow{2}{*}{0,33} & \multirow{2}{*}{0,57} & \multirow{2}{*}{$-1,46$} & \multirow{2}{*}{0,15} & \multirow{2}{*}{$-0,88$} & \multirow{2}{*}{$-2,07$} & \multirow{2}{*}{0,31} \\
\hline & $24-50$ & 11,83 & 3,81 & & & & & & & \\
\hline \multirow{2}{*}{ DISTR } & $18-23$ & 13,25 & 4,02 & \multirow{2}{*}{0,28} & \multirow{2}{*}{0,60} & \multirow{2}{*}{1,74} & \multirow{2}{*}{0,08} & \multirow{2}{*}{1,06} & \multirow{2}{*}{$-0,14$} & \multirow{2}{*}{2,25} \\
\hline & $24-50$ & 12,20 & 4,02 & & & & & & & \\
\hline \multirow{2}{*}{ SUB } & $18-23$ & 12,04 & 4,08 & \multirow{2}{*}{2,33} & \multirow{2}{*}{0,13} & \multirow{2}{*}{0,93} & \multirow{2}{*}{0,35} & & & \\
\hline & $24-50$ & 11,44 & 4,54 & & & & & & & \\
\hline & $18-23$ & 15,01 & 4,18 & & & & & & & \\
\hline & $24-50$ & 16,79 & 3,84 & & & & & & & \\
\hline & $18-23$ & 14,93 & 3,77 & & & & & & & \\
\hline & $24-50$ & 16,12 & 3,81 & & & & & & & \\
\hline
\end{tabular}

\begin{tabular}{|c|c|c|c|c|c|c|c|c|c|c|}
\hline \multirow{2}{*}{ POSI } & $18-23$ & 14,59 & 4,82 & \multirow{2}{*}{1,16} & \multirow{2}{*}{0,28} & \multirow{2}{*}{$-2,45$} & \multirow{2}{*}{$0,02^{*}$} & \multirow{2}{*}{$-1,73$} & \multirow{2}{*}{$-3,12$} & \multirow{2}{*}{$-0,34$} \\
\hline & $24-50$ & 16,32 & 4,49 & & & & & & & \\
\hline \multirow{2}{*}{ SOCSUP } & $18-23$ & 15,82 & 4,99 & \multirow{2}{*}{0,08} & \multirow{2}{*}{0,78} & \multirow{2}{*}{1,17} & \multirow{2}{*}{0,24} & \multirow{2}{*}{0,88} & \multirow{2}{*}{$-0,60$} & \multirow{2}{*}{2,37} \\
\hline & $24-50$ & 14,94 & 5,01 & & & & & & & \\
\hline \multirow{2}{*}{ AVOID } & $18-23$ & 14,99 & 4,48 & \multirow{2}{*}{0,22} & \multirow{2}{*}{0,64} & \multirow{2}{*}{$-0,28$} & \multirow{2}{*}{0,78} & \multirow{2}{*}{$-0,18$} & \multirow{2}{*}{$-1,47$} & \multirow{2}{*}{1,11} \\
\hline & $24-50$ & 15,17 & 4,18 & & & & & & & \\
\hline \multirow{2}{*}{ ESC } & $18-23$ & 12,06 & 4,29 & \multirow{2}{*}{0,07} & \multirow{2}{*}{0,79} & \multirow{2}{*}{1,90} & \multirow{2}{*}{0,06} & \multirow{2}{*}{1,27} & \multirow{2}{*}{$-0,05$} & \multirow{2}{*}{2,59} \\
\hline & $24-50$ & 10,79 & 4,59 & & & & & & & \\
\hline \multirow{2}{*}{ RUMI } & $18-23$ & 15,20 & 5,51 & \multirow{2}{*}{1,55} & \multirow{2}{*}{0,22} & \multirow{2}{*}{$-0,36$} & \multirow{2}{*}{0,72} & & & \\
\hline & $24-50$ & 15,49 & 5,18 & & & & & & & \\
\hline & $18-23$ & 10,38 & 4,92 & & & & & & & \\
\hline & $24-50$ & 8,95 & 5,22 & & & & & & & \\
\hline & $18-23$ & 11,90 & 5,27 & & & & & & & \\
\hline & $24-50$ & 11,30 & 4,80 & & & & & & & \\
\hline
\end{tabular}




\begin{tabular}{|c|c|c|c|c|c|c|c|c|c|c|}
\hline \multirow{2}{*}{$\begin{array}{l}\text { Positive } \\
\text { strategies } \\
\text { total }\end{array}$} & $18-23$ & 12,97 & 2,87 & \multirow{2}{*}{0,77} & \multirow{2}{*}{0,38} & \multirow{2}{*}{$-2,01$} & \multirow{2}{*}{$0,05^{*}$} & \multirow{2}{*}{$-0,82$} & \multirow{2}{*}{$-1,63$} & \multirow{2}{*}{$-0,01$} \\
\hline & $24-50$ & 13,79 & 2,52 & & & & & & & \\
\hline \multirow{2}{*}{$\begin{array}{c}\text { Negative } \\
\text { strategies } \\
\text { total }\end{array}$} & $18-23$ & 12,39 & 4,11 & \multirow{2}{*}{0,00} & \multirow{2}{*}{0,99} & \multirow{2}{*}{1,20} & \multirow{2}{*}{0,23} & \multirow{2}{*}{0,75} & \multirow{2}{*}{$-0,48$} & \multirow{2}{*}{1,99} \\
\hline & $24-50$ & 11,63 & 4,20 & & & & & & & \\
\hline
\end{tabular}

Tab. 6: Results - descriptive statistics and two independent samples t-tests for each coping strategy in both age groups, with Levene's Tests for Equality of Variances

When comparing younger and older students, we can find significant differences in the use of minimization, and also in the use of the positive triad - situation control, reaction control and positive self-instruction. The last significant difference we identified is in the use of the resignation strategy - older students use this strategy less than younger students.

\section{Discussion}

First of all, it is necessary to answer the question: Why is it important to identify and measure the coping strategies of students? This question can be answered in many ways, but from our point of view the most important fact is that stress is usually considered an every-day factor influencing a person's health, achievement, work and social behaviour (Griffin and Clarke, 2011). For that reason, students should include healthrelated behaviour and mostly positive strategies of coping with stress in their behaviour repertoire.

Brunel and Grima (2010) specifically aimed to shed light on the ways in which working students manage their work and school activities. On the basis of questionnaire responses garnered from French working students, they showed that coping strategies implemented to deal with the stress which arises from the work-school conflict are generally effective, with the exceptions of self-accusation and cognitive repression. Furthermore, a negative relationship between work-school conflict, stress and turnover intention emerges. This study goes beyond mere one-dimensional illustrations which portray students as being under pressure or taking action to foster their own professional development, and instead suggests a combined response to role conflict which involves both confronting the conflict and managing emotions.

This study approached the differences in the use of stress coping strategies from two opposing points of view. The first one suggests that role conflict would be the important variable within the process of selecting coping strategies. The second one (according to Folkman et al, 1987, called contextual interpretation) assumes that the use of coping strategies should be more influenced by the specific context, and therefore is the result of what people must cope with as they age, rather than by age itself. The minor differences in the results of both tested hypotheses are most likely due to the relatively small extent of the age rank of the older group of respondents.

Weyers, Ising and Janke (2005) conclude that coping questionnaires, which are based on a dispositional approach and ask about the normal way of reacting in stressful situations, are valid for a certain range of stress intensities, covering most of the considerable range of the intensity dimension. Processing SVF 78 results enables us to analyze stress reduction strategies (positive strategies such as situation control, positive selfinstruction and denial of guilt) or stress intensification strategies (negative strategies such as resignation and rumination). In 
terms of psychometric characteristics, SVF 78 shows high levels of reliability and time stability, consistent construct validity, and considerable external validity with regard to other stress coping inventories (Janke and Erdmann, 2003; Weyers et al, 2005).

\section{Conclusion}

Significantly higher use of the three optimal coping strategies situation control, reaction control and positive self-instructions - by part-time students and older students compared to younger and full-time students, presents the most important finding of this study. Both groups of older students and part-time students don't differ significantly from the Czech population sample. Groups of younger students and full-time students do differ, but in a negative way. Part-time students (as well as older students) also use the minimization strategy more frequently and the resignation strategy less frequently than full-time students and younger students in our sample. However, our sample has its limitations (students of the FEM CULS, prevalence of females), which is why the research results cannot be generalized to the entire Czech population. In this context it could be advisable to extend the further research into the students' well-being and personality issues. Authors consider the results of the research inspiring and thought-provoking, especially in the context of higher education and psychological counselling on prevention of risk behaviour.

\section{Acknowledgements}

This research was supported by the grants number P407/10/1262 and number 43160/1313/3101.

\section{References}

Baltes, B. B., Zhdanova, L. S., \& Clark, M. A. (2011). 'Examining the relationships between personality, coping strategies, and work-family conflict', Journal Of Business And Psychology, Vol. 26, No. 4, pp. 517-530.

Brunel, O., \& Grima, F. (2010). 'Dealing with Work-School Conflict: An analysis of coping strategies. M@N@Gement, Vol. 13, No. 3, pp. 172-202.

Caplan, R. D., Naidu, R. K., Tripathi, R. C. (1984) 'Coping and Defense: Constellations vs. Components', Journal of Health and Social Behavior, Vol. 25, pp. 303-320.

Carver, C. S. et al. (1989) 'Assessing coping strategies: A theoretically based approach,' Journal of Personality and Social Psychology, Vol. 56, No. 2, pp. 267-283.

Chýlová, H., Natovová, L. (2012) 'Stress Coping Strategies at University Students - Part I: Gender Differences', Journal on Efficiency and Responsibility in Education and Science, Vol. 5, No. 3, pp. 135-147, ISSN 1803-1617, [on-line] www.eriesjournal. com/_papers/articel_172.pdf [2012-09-30].

Cicognani, E. (2011) 'Coping Strategies With Minor Stressors in Adolescence: Relationship With Social Support, Self-Efficacy, and Psychological Well-Being', Journal of Applied Psychology, Vol. 41, No. 3, pp. 559-578.

Folkman, S., Lazarus, R. S., Pimley, S., and Novacek, J. (1987) 'Age Differences in Stress and Coping Processes', Psychology and Aging, Vol. 2, No. 2, pp. 171-184. 
Griffin, M. A. And Clarke, S. 'Stress and Well-being at Work' In Zedeck, S. (2011) APA Handbook of Industrial and Organizational Psychology: Volume 3: Maintaining, Expanding, and Contracting the Organization, Washington: American Psychological Association.

Janke, W. and Erdmann, G. (2003) Strategie zvládání stresu SVF 78, Praha: Testcentrum.

Jex, S. M. (1998) Stress and Job Performance, Thousand Oaks: Sage Publications, Inc.

McLaughlin, M., Cormier, L. S. and Cormier, W. H. (1988) 'Relation Between Copipng Strategies and Distress, Stress, and Marital Adjustment of Multiple-Role Women', Journal of Counseling Psychology, Vol. 35, No. 2, pp. 187-193.

Norušis, M. J. (2011) IBM SPSS Statistics 19 Advanced Statistical Procedures, New York: Pearson.

Rantanen, M., Mauno, S., Kinnunen, U., \& Rantanen, J. (2011). Do individual coping strategies help or harm in the work-family conflict situation? Examining coping as a moderator between work-family conflict and well-being. International Journal Of Stress Management, Vol. 18, No. 1, 24-48.

Weyers, P. et al. (2005) 'Comparing two approaches for the assessment of coping: I. Psychometric properties and intercorrelations', Journal of Individual Differences, Vol. 26, pp. 207-212.

Weyers, P., Ising, M. and Janke, W. (2005) 'Effects of imagined stress intensity on responses in a stress coping inventory', Anxiety, Stress and Coping, Vol. 18, No. 2, pp. 117-130. 